JOURNAL OF MECHANICAL ENGINEERING, MANUFACTURES, MATERIALS AND ENERGY

\title{
Analisa Faktor-Faktor yang Mempengaruhi Proses Pengasapan Pada Mesin Pengasapan Ikan Lele
}

\section{Analysis of Factors That Influence The Fumigation Process on Catfish Fumigation Machines}

\author{
Darianto1)*, Hiras Torang Sutrisno Sitohang1), Amrinsyah $^{11}$ \\ Prodi. Teknik Mesin, Universitas Medan Area, Indonesia \\ *darianto0226@yahoo.co.id
}

\begin{abstract}
Abstrak
Indonesia kaya akan sumber hayati, salah satunya adalah gudang sumber penghasil protein hewani khususnya ikan. Pengasapan adalah salah satunya cara pengawetan ikan yang dapat dilakukan dengan peralatan yang sederhana dan mudah didapat serta harganya murah. Tujuan penelitian ini ialah analisa nilai kalor yang dibutuhkan, produktivitas asap, aliran pada lemari pengasapan, dan kadar air pada ikan. Berat ikan yang diasapi dalam penelitian ini adalah $500 \mathrm{~kg}$. Bahan bakar yang digunakan untuk pengasapan ikan adalah kayu jati, dimana kayu ini dipilih sebagai bahan bakar karena sifatnya yang keras, sehingga dapat menghasilkan asap yang tebal dan mengeluarkan aroma yang cukup baik untuk ikan asap. Berdasarkan hasil analisa, besar kalor yang dibutuhkan dalam satu siklus proses pengasapan ikan ialah $375.000 \mathrm{kkal}$. Bahan bakar yang digunakan sebelum finishing pengasapan yaitu sebanyak 120 kg dan untuk finishing pengasapan menggunakan bahan bakar sebanyak $30 \mathrm{~kg}$. Bilangan Re dari proses pengasapan ialah 12450 atau lebih besar dari 4000. Oleh karena itu, jenis aliran yang mengalir pada dapur pengasapan ialah jenis turbulen. Kadar air yang masih tersisa dalam produk ialah 13,4 \%. Hal ini masih dibawah batas ambang yang dipersayaratkan oleh SNI, yaitu maksimal $60 \%$.
\end{abstract}

Kata Kunci: Kayu keras; waktu pengasapan deal; kadar air

\begin{abstract}
Indonesia is rich in biological resources, one of which is the source of the largest producer of animal protein, especially fish. Fumigation is one of the ways to preserve fish that can be done with equipment that is simple and easily available and cheap. The purpose of this study was to analyze the heating value needed, the productivity of smoke, the flow in the fumigation cupboard, and the water content in fish on a catfish fumigation machine. The weight of the smoked fish in this study was $500 \mathrm{~kg}$. The fuel used for fumigation is teak wood, where the wood has a hard nature, produces thick smoke, and produces a good enough aroma for smoked fish. Based on the results of analysis, the amount of heat needed in one cycle of catfish fumigation process is 375,000 kcal. The fuel used before fumigation finishing is $120 \mathrm{~kg}$ and for smoked finishing is 30 $\mathrm{kg}$. Re number from the fumigation process is 12450 or greater than 4000 . Therefore, the type of flow that flows in the fumigation kitchen is a type of turbulent. The remaining water content in the product is $13.4 \%$. This is still below the threshold required by SNI, which is a maximum of $60 \%$.
\end{abstract}

Keywords: Hardwood, Time fogging deal, Moisture content

How to Cite: Darianto, 2018. Analisa Faktor-Faktor yang Mempengaruhi Proses Pengasapan Pada Mesin Pengasapan Ikan Lele, JMEMME, 2 (2): 56-66 


\section{PENDAHULUAN}

Indonesia kaya akan sumber hayati, salah satunya adalah gudang sumber penghasil protein hewani khususnya ikan. Negara kita juga kaya akan keanekaragaman perikanan baik ikan laut maupun ikan tawar. Ikan memang mengandung komposisi gizi yang ideal. Ikan mengandung 18 persen protein terdiri atas asam amino esensial yang tidak rusak pada waktu pemasakan. Kandungan lemaknya 1-20 persen lemak yang mudah dicerna serta langsung dapat digunakan oleh jaringan tubuh. Kandungan lemaknya sebagian besar adalah asam lemak tak jenuh yang dapat dibutuhkan untuk pertumbuhan dan dapat menurunkan kolesterol darah.

Pengasapan adalah salah satu cara pengawetan ikan yang dapat dilakukan dengan peralatan yang sederhana dan mudah didapat serta harganya murah. Ikan yang diolah dengan cara pengasapan dapat bertahan lebih lama disebabkan beberapa faktor, diantaranya berkurangnya kadar air ikan dibawah 40 persen, adanya senyawasenyawa asam kayu yang dapat menghambat pertumbuhan mikroorganisme pembusuk, dan terjadinya koagulasi protein pada permukaan ikan yang mengakibatkan jaringan pengikat menjadi lebih kuat dan kompak sehingga tahan terhadap serangan mikroorganisme. Senyawa-senyawa antimikroba yang terdapat dalam asap antara lain: berbagai macam aldehida, alcohol, asam, dan sebagainya. Pengasapan juga dapat memperbaiki penampakan ikan karena ikan menjadi terlihat berminyak atau mengkilat.

Sektor perikanan sebagai salah satu pendukung sektor ekonomi memiliki peran dalam pembangunan ekonomi nasional, yaitu memberikan nilai tambah dan mempunyai nilai strategis, serta dapat memberikan manfaat finansial maupun ekonomi, khususnya dalam penyediaan bahan pangan protein, perolehan devisa, dan penyediaan lapangan kerja. Sejauh ini pembangunan perikanan yang dilakukan telah menunjukkan hasil yang nyata dan positif terhadap pembangunan nasional. Hal ini terlihat dari sumbangan produk domestik bruto (PDB) sektor perikanan terhadap PDB nasional yang terus meningkat. Kontribusi sektor perikanan dan kelautan terhadap PDB nasional yang mencapai sekitar 12,4\%. Bahkan industri perikanan menyerap lebih dari 16 juta tenaga kerja secara langsung (Dahuri, 2004).

Salah satu metode pengawetan ikan adalah dengan metode pengasapan selain disimpan dalam suhu rendah, diasinkan, atau di-presto. Dengan metode pengawetan ini daging ikan yang biasanya membusuk dalam waktu singkat dapat disimpan dalam suhu kamar untuk jangka waktu berbulan-bulan, walaupun biasanya harus ditutup rapat.

Ikan sebagai bahan makanan mengandung protein tinggi dan mengandung asam amino esensial yang diperlukan oleh tubuh, disamping itu nilai biologisnya mencapai 90\%, dengan jaringan pengikat sedikit sehingga mudah dicerna oleh konsumen (Adawyah, 2007). Dengan demikian prinsip pembuatan olahan ikan asap merupakan salah satu cara untuk memperpanjang daya simpan dan menambah nilai jual dari produk tersebut.

Selain keuntungan-keuntungan tersebut, pengasapan ikan mempunyai 


\section{Darianto, Analisa Faktor-Faktor yang Mempengaruhi Proses Pengasapan Pada Mesin \\ Pengasapan Ikan Lele}

beberapa kelemahan karena tekstur ikan berubah menjadi keras terutama jika pengasapan dilakukan pada suhu rendah dalam waktu lama dan diperlukan waktu lama untuk melakukan pengasapan ikan yang sempurna. Sedangkan yang teksturnya keras diperlukan proses dehidrasi (pembasahan kembali) sebelum ikan dapat dikonsumsi.

Pertumbuhan jamur pada ikan asap menyebabkan terjadinya perubahan bau menjadi tengik dan perubahan tekstur. Pengolahan ikan dengan menggunakan asap untuk komsumsi manusia sudah dikenal sejak zaman dahulu, tetapi cara pengolahannya sederhana, biaya murah dan mudah dikerjakan. Dibandingkan dengan ikan asin, ikan asap lebih unggul baik dari segi rasa (kelezatan), gizi, dan juga harga jualnya. Meskipun mempunyai beberapa ke unggulaan, di Indonesia maupun Asia ikan asap masih kalah dalam proses penjualan dibandingkan dengan ikan asin.

Ikan asap harus diolah lagi dengan menambah bumbu-bumbu lainnya. Selain itu, ada anggapan ikan asap dapat menimbulkan penyakit kanker atau bersifat kansirgernik. Alasan ini karena ikan asap mengandung senyawa yang dicurigai menjadi penyebab kanker, yaitu Pilicylic Aromatic Hydrocarbon (PAH).

Senyawa PAH yang ditakuti ternyata ditemukan juga dimakanan olahan lain seperti: roti, biskuit, kopi, minyak kedelai, sate, ikan bakar, ikan kaleng, dan bahkan pada ikan segar termasuk kepiting, udang, dan lobster. Dibandingkan dengan olahan lain, kandungan PAH pada ikan asap masih tergolong rendah. Sementara senyawa vitamin A dan anti oksida mampu menghambat daya karsinogenik PAH. Dari penelitian-penelitian yang dilakukan, ikan asap dan juga makanan asap lainnya bukanlah penyebab karsinogenik yang membahayakan manusia yang mengomsusinya. Ikan asap ini umumnya cukup popular dan digemari di daerah Sumatera. Kalimantan, dan Sulawesi serta dijawa. Jenis ikan yang banyak di gemari setelah diasap adalah ikan bandeng, cakalang, tongkol, dan tuna. Harga jualnya cukup tinggi.

Dengan meningkatnya tingkat pendidikan, kesejahteraan, dan kesadaran akan hidup sehat, pola komsumsipun ikut bergeser dan peluang ikan asap untuk digemari makin terbuka. Disisi lain, semakin berkembangnya alat tangkap ikan, hasil tangkapanpun terus meningkat sehingga pemanfaatan untuk ikan asappun akan meningkat. Hal ini menjadikan ikan asap kian menarik untuk digeluti dan dapat dijadikan usaha yang menguntungkan.

Produk hasil pengasapan (ikan asap) merupakan produk yang disukai oleh konsumen, namun beberapa ikan asap memiliki daya awet yang tidak tahan lama. Daya awet dan mutu ikan asap dapat dipertahankan dengan melakukan penyimpanan yang baik dan benar. Salah satu teknik penyimpanan yang biasa dilakukan terhadap produk ikan asap yaitu penyimpanan dingin atau penyimpanan suhu rendah.

Ikan salah satu komoditas ungglan perikanan budidaya air tawar. Produksi nominal ikan lele dari tahun 2010 sampai dengan tahun 2014 mengalami kenaikan dari 242.811 ton menjadi 463.221 ton. Nilai rata-rata produksi lele mencapai 37,49\% (Ditjen Budidaya KKP, 2014). Perkembangan yang pesat dan tingginya 
produksi budidaya ikan lele diduga karena ikan lele dapat dibudidayakan di lahan dan sumber air yang terbatas dengan padat tebar tinggi, teknologi budidaya relative mudah dan dikuasai oleh masyarakat, pemasarannya relatif mudah serta modal usaha budidaya lele yang diburuhkan relatif rendah. Saat ini teknologi pembesaran lele semakin berkembang, diantaranya adalah teknologi kolam terpal dan permanen.

Ikan lele mempunyai protein tinggi 17,7-26,7\% dan lemaknya berkisar 0,95 sampai dengan $11,5 \%$ (Nurimala et al 2009). Ikan lele dapat dikelompokkan kedalam bahan pangan berprotein sedang dengan lemak rendah (Rosa et al., 2007). Kandungan komponen gizi ikan lele mudah dicerna dan diserap oleh tubuh manusia baik pada anak-anak dewasa, dan orang tua (Rohimah et al., 2014).

Tujuan penelitian ini ialah analisa nilai kalor yang dibutuhkan, produktivitas asap, aliran pada lemari pengasapan, dan kadar air pada ikan.

\section{METODE PENELITIAN}

Prosedur Pengasapan Ikan Lele ialah sebagai berikut:

\section{a. Proses Penggaraman Ikan Lele}

Tahap awal sebelum melakukan proses pengasapan ikan lele yaitu, menyediakan bahan baku utama yaitu ikan lele. Setelah ikan lele tersedia, ikan lele dibelah dengan alat potong. Selanjutnya, ikan di masukkan kedalam drum yang telah berisi air yang sudah di garami. Dalam satu drum berisi air dimasukkan garam sebanyak 3 bungkus dengan ukuran garam perbungkus 500 gram. Setelah ikan dimasukkan didalam drum, ikan dibiarkan berada dalam drum selama 30 menit. Proses ini diperlihatkan pada gambar 1.

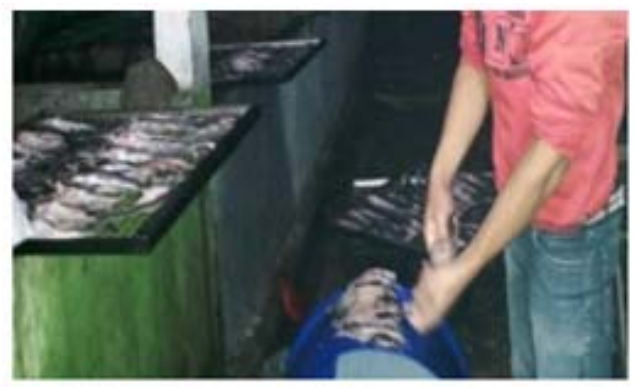

Gambar 1. Proses Penggaraman Sumber(Gambar Penggaraman ikan di Home Indutri Jl Perjuangan)

\section{b. Proses Pengasapan tahap awal}

Setelah proses penggaraman selesai, ikan di bilas dan ditiriskan diatas rak selama 15 menit dengan tujuan sebelum masuk kedalam dapur pengasapan kadar air yang berada dalam ikan berkurang. Setelah ikan ditiriskan, ikan dimasukkan kedalam lemari. Untuk mendapatkan aliran asap yang merata jarak antara ikan di rak paling bawah atau yang paling dekat dengan sumber asap tidak terlalu rapat sehingga aliran asap dari bawah bisa sampai ke rak paling ata, sehingga dapat diperoleh aliran turbulensi pengasapan yang merata. Dalam pemanasan tahap awal, suhu lemari asap diatur hingga sekitar $40-60^{\circ} \mathrm{C}$ selama 3 jam. Dalam pemanasan awal posisi bagian daging (potongan) menghadap kebawah dengan tujuan agar penurunan kadar air dalam daging dapat lebih cepat. Setelah pemanasan awal berlangsung selama 15 menit ikan ditarik keluar dari lemari pengasapan dan posisi ikan dibalik, dimana bagian kulit ikan menghadap sumber asap dan setelah posisi ikan diganti ikan dimasukkan kembali kedalam lemari 


\section{Darianto, Analisa Faktor-Faktor yang Mempengaruhi Proses Pengasapan Pada Mesin \\ Pengasapan Ikan Lele}

pengasapan. Proses pengasapan tahap awal diperlihatkan pada gambar 2 .

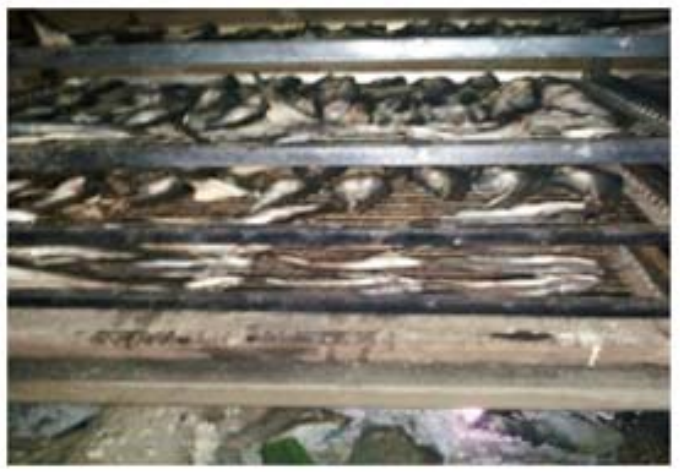

Gambar2. Proses pengasapan tahap awal Sumber (Gambar Pengasapan tahap awal di home industri di Jl Perjuangan)

Posisi rak juga diganti, dimana rak pertama diganti menjadi rak nomor sepuluh dan begitu juga seterusnya dengan rak yang lain. Hal ini dilakukan untuk menghindari agar ikan terlalu cepat kering sehingga proses pengeringan menjadi tidak merata. Pengasapan dilakukan dan diteruskan sampai permukaan ikan berwarna kekuningan atau coklat kekuningan. Pada keadaan ini ikan dianggap telah cukup untuk mencegah terjadinya pelendiran.

\section{c. Pengasapan tahap kedua}

Pengasapan tahap kedua dilakukan pada suhu $65-70^{\circ} \mathrm{C}$ selama 2 jam. Pada pengasapan ini diperlukan ketelitian karena suhu yang tinggi sangat mempengaruhi tekstur ikan. Pada suhu tinggi ikan bisa saja mengalami terlalu kering, dimana bisa mengakibatkan tekstur ikan menjadi terlalu rapuh. Jika tekstur ikan terlalu rapuh, maka ikan akan semakin keras dan protein yang ada dalam ikan menjadi berkurang. Selain itu, ikan juga akan susah dipasarkan karena tekstur ikan terlalu keras sehingga kurang diminati masyarakat. Sebaliknya jika suhu pengasapan tidak sesuai lamanya dengan waktu pengasapan maka ikan tidak kering. Jika hal ini terjadi maka ikan akan lebih mudah terserang jamur. Kondisi dapur pengasapan pada proses tahap kedua diperlihatkan pada gambar 3 .

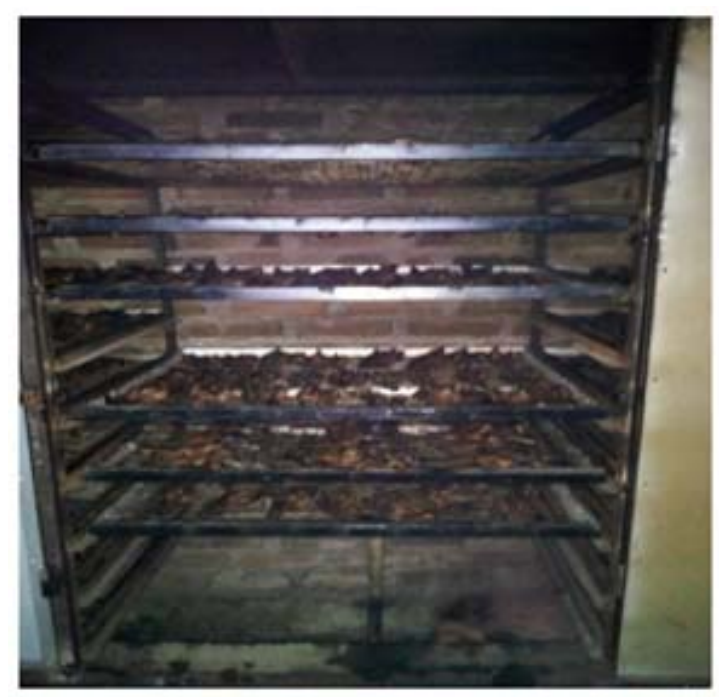

Gambar 3. Hasil pengasapan tahap kedua Sumber( Hasil pengujian pengasapan tahap kedua di home industri di Jl perjuangan)

\section{Keberhasilan Proses Pengasapan}

Tingkat keberhasilan proses pengasapan ikan tergantung pada empat faktor utama (selain bahan baku) yang saling berkaitan, yaitu:

- Mutu dan Volume asap

- Suhu dan kelembaban ruang pengasapan

- Waktu Pengasapan

- Sirkulasi Udara dalam Ruang Pengasapan (Pengaruh Turbulensi asap pada Hasil Pengasapan Ikan Lele) 


\section{Mutu dan volume asap}

Mutu dan volume asap yang dihasilkan tergantung pada jenis kayu yang digunakan dalam proses pengasapan. Dalam penelitian ini digunakan kayu jati. Kayu ini digunakan karena untuk mendapatkan mutu dan volume asap yang sesuai yang diharapkan, sebaiknya digunakan jenis kayu yang keras (nonresinous). Selain itu kayu bakau, rasa mala, dan tempurung kelapa bisa juga digunakan sebagai bahan bakar. Asap yang dihasilkan dari pembakaran kayu keras akan berbeda komposisinya dengan asap yang dihasilkan dari pembakaran kayu lunak. Pada umumnya kayu keras akan menghasilkan aroma yang lebih unggul, lebih kaya kandungan aromatic dan lebih banyak mengandung senyawa asam dibandingkan kayu lunak. Pada penggunaan kayu keras, asap yang dihasilkan gumpalan asap yang tebal dan tidak terlalu menyebar. Bila menggunakan kayu lunak (resinous), asap yang dihasilkan banyak mengandung senyawa yang dapat menimbulkan hal dan bau yang tidak di inginkan. Dengan kata lain jenis kayu yang digunakan sebagai sumber asap sebaiknya memenuhi tiga syarat, yaitu keras, tidak mudah/cepat terbakar, dapat menimbulkan asap dalam jumlah yang besar dan dalam waktu yang lama. Dalam penelitian ini bahan bakar yang digunakan bahan bakar padat alami yaitu bahan bakar kayu (wood).

\section{Suhu dan kelembapan ruang pengasapan.}

Kondisi ruang pengasapan juga sangat menentukan mutu ikan asap. Ruangan pengasapan ikan adalah ruangan yang memiliki suhu dan kelembapan udara cukup rendah. Banyaknya uap air yang diserap oleh udara tergantung suhunya, jadi bila udara cukup dingin $30^{\circ} \mathrm{C}$ dipanasi maka kapasitas pengeringan akan lebih tinggi. Dalam keadaan lembab, uap jenuh yang telah panas tidak dapat dipanasi lagi secara tepat untuk mengurangi kandungan uap airnya dan oleh karena itu, kapasitas menurun. Jika suhu ruang pengasapan cukup rendah, asap yang dihasilkan dari proses pengasapan di udara terbuka (bersuhu relatif tinggi ). Dengan demikian, volume asap yang dapat melekat pada tubuh ikan menjadi lebih banyak dan merata. Apabila proses pengasapan ikan berlangsung dalam ruangan bersuhu tinggi, permukaan kulit atau tubuh bagian luar akan menjadi cepat kering atau mengeras (dapat menghalangi proses penguapan cairan yang terdapat pada bagian tubuh yang lebih dalam), sehingga proses pembusukan masih mungkin terjadi pada tubuh ikan bagian dalam.

\section{Waktu Pengasapan}

Metode pengasapan panas pada ikan memerlukan 2 proses berurutan yaitu pengasapan diikuti oleh pemasakan (Rasco, 2009). Lama waktu pengasapan tergantung pada flavor dan kelembapan yang di inginkan. Lama waktu pengasapan sangat berpengaruh terhadap kualitas ikan. Dan dari lamanya waktu pengasapan akan menghasilkan warna ikan yang kecoklatan dan kehitaman. Dalam penelitian ini dibutuhkan waktu pengasapan dari tahap awal sampai akhir selam 8 jam.Dan dari hasil pengamatan ikan berwarna kecoklatan, tentu warna ini dihasilkan dari jenis kayu yang digunakan selama pengasapan. 


\section{Darianto, Analisa Faktor-Faktor yang Mempengaruhi Proses Pengasapan Pada Mesin Pengasapan Ikan Lele}

\section{Sirkulasi Udara Dalam Ruang Pengasapan}

Adanya sirkulasi udara yang baik di dalam ruang pengasapan menjamin mutu ikan asap yang lebih sempurna. Sirkulasi udara yang baik akan menjaga suhu dan kelembapan ruang pengasapan tetap konstan selama proses pengasapan berlangsung. Selain itu, aliran asap akan berjalan lancar dan kontiniu, sehingga partikel asap yang menempel pada tubuh ikan akan menjadi lebih banyak dan merata. Jadi pada tahap pengasapan, kecepatan penguapan air tergantung pada kapasitas pengering udara dan asap juga kecepatan pengaliran asap. Pada tahap kedua, di mana permukaan ikan sudah agak kering, suhu ikan akan mendekati suhu udara dan asap. Kecepatan pengeringan akan menjadi lambat karena air harus merembes dahulu dari lapisan dalam daging ikan, bila pengeringan mulamula dilakukan pada suhu yang terlalu tinggi dan terlalu cepat, maka permukaan ikan akan menjadi keras dan akan menhambat penguapan air selanjutnya dari lapisan dalam, sehingga kemungkinan daging ikan bagian dalam tidak mengalami efek pengeringan.

Pengaruh Turbulensi asap pada Hasil Pengasapan Ikan Lele

Aliran turbulen adalah aliran fluida yang partikel-partikelnya bergerak secara acak dan tidak stabil dengan kecepatan berfluktuasi yang saling interaksi.Akibat dari hal tersebut garis alir antar partikel fluidanya saling berpotongan. Oleh Osborne Reynold digambarkan sebagai bentuk yang tidak stabil yang bercampur dalam waktu yang cepat yang selanjutnya memecah dan menjadi takterlihat.Pada arus turbulen, massa air bergerak keatas, kebawah, dan secara lateral berhubungan dengan arus yang umum, memindahkan massa dan momentum. Dengan gerakan tidak beraturan seperti itu, massa atau gumpalan fluida akan mempunyai percepatan menyimpang yang hanya sedikit persenrtasinya dari kecepatan ratarata, meskipun begitu arus turbulen bersifat menentukan arus, sebab turbulen menjaga partikel-partikel dalam suspense, secara konstan, seperti clay dan slit pada sungai dan pasir pada sungai dan pada pasir pada arus turbidit, atau secara berangsur seperti pada kebanyakan butir pasir disungai, pantai dan bukit pasir.

Turbulensi asap pada lemari pengasapan sangat berpengaruh pada hasil dan lamanya waktu pengasapan. Pada penelitian ini turbulensi asap yang terjadi dalam lemari pengasapan sangat berpengaruh positif karena arah asap yang ada didalam lemari pengasapan sifatnya bolak-balik. Jadi, hal ini sangat menguntungkan pada ikan yang berada didalam lemari pengasapan. Dimana ikan akan terkena asap dengan waktu yang lama. Berbeda halnya jika menggunakan aliran laminar atau searah.Asap lebih banyak terbuang ke udara bebas sehingga waktu yang dibutuhkan untuk pengasapan lebih banyak. Hal ini juga sangat memepengaruhi juga dengan bahan bakar, dimana bahan akan lebih banyak habis.

\section{HASIL DAN PEMBAHASAN}

Volume dapur pengasapan ikan lele, ialah $=\mathrm{P} \times \mathrm{l} \times \mathrm{t}=4 \mathrm{~m} \times 0,8 \mathrm{~m} \times 1,20 \mathrm{~m}=3,84$ $\mathrm{m}^{3}$. Selanjutnya Volume lemari pengasapan ikan dibagi dengan jumlah ikan yang akan diasapi dalam lemari pengasapan. Dalam penelitian ini, jumlah berat ikan yang di 
asapi adalah $500 \mathrm{~kg}$, dimana rata-rata $1 \mathrm{~kg}$ ikan berjumlah 10 ekor ikan. Maka 500 kg ikan = 5000 ekor. Volume dibagi dengan jumlah ikan ialah:

$$
\begin{aligned}
& \mathrm{V}=3,84 \mathrm{~m}^{3} / 5000 \\
& =0,000768 \mathrm{~m}^{3} / \text { ekor. }
\end{aligned}
$$

\section{Pengujian nilai kalor pada komposisi kimia} kayu.

Pada penelitian ini, kayu yang digunakan sebagai bahan bakar adalah kayu yang sifatnya keras. Selanjutnya ini akan diasumsikan bahwa semua carbon akan teroksidasi menjadi karbon monoksida (CO) sebelum setiap carbon berubah menjadi carbon dioksida (CO2). Reaksi kimianya sebagai berikut :

$48,5 \mathrm{C}+\mathrm{O}_{2} \quad 48,5 \mathrm{CO}+\mathrm{Q}_{\text {c.со }}=121250$

$\mathrm{kJ} / \mathrm{kg} \mathrm{mol}$

Cross Kcal $/ \mathrm{kg}($ Wood $)=2500 \mathrm{kkal} / \mathrm{kg}$

Jumlah kalori yang digunakan pada bahan bakar pengasapan :

Nilai kalori bahan bakar kayu (Wood) = $2500 \mathrm{kkal} / \mathrm{kg} \mathrm{x}$ jumlah bahan bakar yang digunakan selama proses pengasapan.

$$
\begin{aligned}
& =2500 \mathrm{kkal} / \mathrm{kg} \times 150 \mathrm{~kg} \\
& =375.000 \mathrm{kkal} .
\end{aligned}
$$

Maka, jumlah kalori yang terdapat dalam bahan bakar selama pengasapan adalah $375.000 \mathrm{kkal}$.

Oksigen yang dibutuhkan:

$$
=\frac{375.000 \times 32}{24,02}=\frac{12000000}{24,02}=495867,77 \mathrm{~kg} \mathrm{O}_{2}
$$

Hidrokarbon mempunyai temperature pembakaran yang tertinggi yaitu : $582{ }^{\circ} \mathrm{C}$. Tetapi selama dia berbentuk gas hydrogen beroksidasi menjadi air seperti diperlihatkan dalam persamaan reaksi kimia di bawah ini :

$$
2 \mathrm{H}+\mathrm{O}_{2} \mathrm{H}_{2} \mathrm{O}+2 \mathrm{Q}_{\mathrm{H}}=7.500 .000 \mathrm{kj} / \mathrm{kg}
$$
mol H
Jadi, kebutuhan oksigen untuk pembakaran (pengasapan) 5000 ekor ikan adalah :

$$
\frac{5000 \times 32}{4,032 \times}=39682,54
$$

jadi $39682,54 \mathrm{O}_{2} / \mathrm{kg} \mathrm{H}_{2}$

Nilai Panas (Heating Value)

Nilai panas (Heating Value) atau nilai kalor (Calorific Value) dari unsur-unsur carbon, Hidrogen dan sulfur adalah sebagai berikut :

Nilai panas carbon :

$$
\begin{aligned}
Q_{\text {c-co }} & =121250 \mathrm{~kJ} / \mathrm{kg} \cdot \mathrm{mol} \mathrm{C} \\
& =\frac{121250}{12,01} \\
& =10104,17 \mathrm{~kJ} / \mathrm{kg} \mathrm{C} \\
& =10104,17 \times 0,2388 \\
& =3314,17 \mathrm{kkal} . \mathrm{mol} \mathrm{CO} \\
\text { Qco-co } 2 & =375000 \mathrm{kj} / \mathrm{kg} \cdot \mathrm{mol} \mathrm{CO} \\
= & \frac{375000}{28,010} \\
= & 13388,075 \mathrm{~kJ} / \mathrm{kg} \cdot \mathrm{mol} \mathrm{C} \\
= & 3197,53 \mathrm{kkal} . / \mathrm{kg} \mathrm{CO}
\end{aligned}
$$

Dalam hal Nilai Panas (kalor) Carbon tidak ada nilai tertinggi dan terendah, karena tidak ada kehilangan energy panas selama terjadinya reaksi kimia.

Nilai panas Hidrogen :

$\mathrm{Q}_{\mathrm{h}}=2250000 \mathrm{~kJ} / \mathrm{kg} \cdot \mathrm{mol} \mathrm{H}_{2}$

$$
=\frac{2250000}{2,016}
$$

$=1116071,43 \mathrm{kj} / \mathrm{kgH}_{2}$

= 266556,35 kkal $/ \mathrm{kg} \mathrm{H}_{2}$

Dalam peristiwa oksidasi $\mathrm{H}_{2}$ terbentuk $\mathrm{H}_{2} \mathrm{O}$ (air) yang dalam tempo relatif singkat berubah menjadi uap air $\left(\mathrm{H}_{2} \mathrm{O}\right)$. Dalam peristiwa perubahan fasa ini dibutuhkan panas laten (Laten Heat) yang besarnya tergantung pada keadaan sekelilingnya (tekanan dan suhu). Dalam lemari pengasapan diestimasikan tekanan 


\section{Darianto, Analisa Faktor-Faktor yang Mempengaruhi Proses Pengasapan Pada Mesin \\ Pengasapan Ikan Lele}

sama dengan satu atmosfir mutlak, jadi panas laten air:

$\mathrm{L}_{\mathrm{H} 2} \mathrm{O}=539,8 \mathrm{kkal} / \mathrm{kg}$

Nilai Panas $\mathrm{H}_{2}$ sebelum dikurangi panas pembentuk uap disebut N. Nilai Panas kotor ( Tertinggi ) atau Gross ( Higher ) Heating Value.

Jadi : $\mathrm{HHV}_{\mathrm{h}}=3197,53 \mathrm{kkal} / \mathrm{kg} \mathrm{H}$

$\mathrm{LHV}_{\mathrm{h}}=266556,35 \mathrm{kkal} / \mathrm{kg} \mathrm{H}$

\section{Pengujian produktivitas Asap}

Berat bahan bakar yang berbeda sangat pengaruh besar dengan kecepatan pembakaran, dimana bahan bakar yang mempunyai berat $5 \mathrm{~kg}$ sangat mudah terbakar dan menghasilkan gumpalan asap yang kurang sempurna. Biasanya bahan bakar yang mempunyai berat kurang lebih $5 \mathrm{~kg}$ digunakan di awal pengasapan. Sedangkan bahan bakar yang mempunyai berat $20 \mathrm{~kg}$ lebih bagus dari ukuran yang sebelumnya dimana ukuran yang $20 \mathrm{~kg}$ lebih lama terbakar dan menghasilkan gumpalan asap yang lebih tebal. Bahan bakar yang ukurannya $20 \mathrm{~kg}$ digunakan di pertengahan pengasapan. Lebih bagusnya yaitu dengan menggunakan bahan bakar kayu yang mempunyai berat $30 \mathrm{~kg}$. Dimana bahan bakar yang mempunyai ukuran lebih berat akan menghasilkan gumpalan asap yang lebih tebal dan proses pembakarannya lebih lama. Jumlah bahan bakar yang digunakan selama pengasapan $\pm 150 \mathrm{~kg}$. Komposisi berat bahan bakar yang dipergunakan diperlihatkan pada gambar 4.

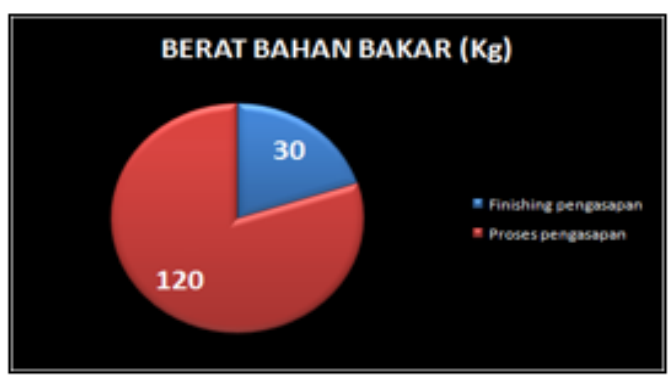

Gambar 4. Penggunaan bahan bakar selama proses pengasapan

Dari grafik diatas menunjukkan bahwa bahan bakar yang digunakan sebelum finishing pengasapan yaitu sebanyak 120 kg. Dan untuk finishing pengasapan menggunakan bahan bakar sebanyak $30 \mathrm{~kg}$. Dalam penelitian ini banyaknya bahan bakar yang digunakan selama proses pengasapan tidak sama dengan jumlah bahan bakar yang digunakan untuk finishing karena untuk finishing suhu pengasapan tidak boleh terlalu panas karena dapat merusak tekstur ikan.

Pengujian aliran pada lemari pengasapan

Besarnya bilangan reynold yang terjadi pada suatu aliran dalam lemari pengasapan dapat menunjukkan apakah profil aliran tersebut laminar atau turbulen. Biasanya angka $\mathrm{Re}<2000$ merupakan batas aliran laminar dan angka lebih besar dari Re $>4000$ dikatakan aliran turbulen. Sedangkan Rd diantara keduanya dinyatakan

Dari hasil pengujian alat ukur flow meter $\mathrm{v}=10-6 \mathrm{~m}^{2} /$ det

$$
\begin{aligned}
\mathrm{V} & =0,15 \mathrm{~m}^{3} / \mathrm{det} \\
\operatorname{Re} & =\frac{V \cdot D}{v}=\frac{1,5 \cdot 0,083}{10^{-6}}=12450 \\
& >4000(\text { Aliran turbulent })
\end{aligned}
$$


Turbulensi asap pada lemari pengasapan sangat berpengaruh pada hasil dan lamanya waktu pengasapan. Pada penelitian ini turbulensi asap yang terjadi dalam lemari pengasapan sangat berpengaruh positif karena arah asap yang ada didalam lemari pengasapan sifatnya bolak balik. Jadi, hal ini sangat menguntungkan pada ikan yang berada didalam lemari pengasapan. Dimana ikan akan terkena asap dengan waktu yang lama. Berbeda halnya jika menggunakan aliran laminar atau searah. Asap lebih banyak terbuang ke udara bebas sehingga waktu yang dibutuhkan untuk pengasapan lebih banyak.

Pengujian Kadar Air pada ikan setelah diasapi

Standar nilai kadar air ikan asap berdasarkan SNI adalah maksimal 60\%. Tingginya kadar air, disebaabkan oleh lama waktu pengasapan yang relative pendek dan suhu pengasapan yang fluktuatif, sehingga menyebabkan proses penguapan air menjadi tidak stabil dan nilai kadar air masih tinggi. Terjadinya penurunan kadar air dimungkinkan akibat penguapan dari produk karena suhu udara dan kelembaban lingkungan sekitar. Dalam penelitian ini perlu kita ketahui kandungan air yang ada pada ikan sebelum disapi.

Pada penelitian ini penghitungan kadar air pada ikan lele yang sudah diasapi di uji di Balai riset dan Standarisasi Industri Medan dengan metode SNI 01- 2891 1992. Dan dari hasil uji kadar air pada ikan lele yang sudah diasapi dihasilkan 13,4\%. Dengan hasil ini dapat disimpulkan bahwa sirkulasi asap didalam dapur pengasapan yang arahnya turbulen sangat membantu kepada penurunan kadar air yang ada pada ikan.

\section{SIMPULAN}

Berdasarkan hasil penelitian, besar kalor yang dibutuhkan dalam satu siklus proses pengasapan ikan ialah $375.000 \mathrm{kkal}$. Bahan bakar yang digunakan sebelum finishing pengasapan yaitu sebanyak 120 $\mathrm{kg}$ dan untuk finishing pengasapan menggunakan bahan bakar sebanyak 30 kg. Bilangan Re dari proses pengasapan ialah 12450 atau lebih besar dari 4000 . Oleh karena itu, jenis aliran yang mengalir pada dapur pengasapan ialah jenis turbulen. Hal ini cukup baik untuk proses pengasapan karena ikan akan terkena asap dengan waktu yang cukup lama. Berdasarkan hasil uji kadar air pada ikan lele yang sudah diasapi, diperoleh bahwa kadar air yang masih tersisa dalam produk ialah 13,4 \%. Hal ini masih dibawah batas ambang yang dipersayaratkan oleh SNI, yaitu maksimal 60\%.

\section{UCAPAN TERIMAKASIH}

Terima kasih diucapkan kepada Program Studi Teknik Mesin, Universitas Medan Area yang telah memberikan dukungan selama penelitian berlangsung. Ucapan terima kasih juga untuk tim peneliti yang telah bekerjasama dengan baik selama penelitian berlangsung.

\section{DAFTAR PUSTAKA}

Adayah, R. 2007 .Pengolahan dan pengawetan ikan.. Bumi Aksara Jakarta.

Badan Standarisasi Nasional, 2006.SNI 01-4872.12006. Es untuk penanganan penanganan ikan I:Spesifikasi. Jakarta. 


\section{Darianto, Analisa Faktor-Faktor yang Mempengaruhi Proses Pengasapan Pada Mesin Pengasapan Ikan Lele}

Badan Standarisasi Nasional. 2000. SNI o1-4435200o. Garam bahan baku untuk industry garam beryodium. Jakarta.

Budiman, M.S. 2004. Teknik penggaraman dan pengeringan.Departemen Pendidikan Nasional. Direktorat Pemasaran Dalam Negeri. 2012. Warta Pasar Ikan dan Kemandirian Pangan. Dirjen PPHP Effendi, M.I. 1979. Biologi Perikanan. Yayasan Pustaka Tama. Yogyakarta. Ishikawa K. 1998. Teknik Penuntun Pengendalian Mutu ( Terjemahan ). Di dalam Muhandri T dan D.

Haruwati, E.S. 2002.Pengolahan Ikan Secara Tradisional Prospek dan Peluang Pengembangan.Jurnal Litbang Pertanian 21 (3).

Hermana, 1991. Iradiasi Pangan Cara Mengawetkan dan Meningkatkan Keamanan Pangan

Hanafi Madura. Makalah Ikan AsapSosis Fermentasi dan Agroindustri Ikan lele-Nisa, $d k k$

IR.M.J.Djokosetyardjo : KETEL UAP

IR.Syamsir A. Muin : Pesawat-pesawat konversi energy 1 (KETEL UAP)

Kasarisma.Siatem jaminan Mutu Industri Pangan. Bogor. IPB Press. Moeljianto R. 1992. 